\title{
Cystostomy Site
}

National Cancer Institute

\section{Source}

National Cancer Institute. Cystostomy Site. NCI Thesaurus. Code C122641.

A surgically created external opening into the anterior wall of the bladder. 